\title{
Brak związku pomiędzy pochodzącą od człowieka neandertalskiego transwersją g.50318299T>G genu HYAL2 a predyspozycją do bliznowca
}

\author{
Neanderthal-derived g.50318299T>G transversion of the HYAL2 gene is not associated \\ with the predisposition to keloid scarring
}

\author{
Andrzej Dmytrzak², Agnieszka Małyszek², Agnieszka Bińczak-Kuleta², Beata Łoniewska³ \\ Andrzej Ciechanowicz ${ }^{2}$ \\ ${ }^{1}$ Aesthetic Med, ul. Niedziałkowskiego 47, 71-403 Szczecin \\ ${ }^{2}$ Pomorski Uniwersytet Medyczny w Szczecinie, Zakład Biochemii Klinicznej i Molekularnej, al. Powstańców Wlkp. 72, 70-111 Szczecin \\ ${ }^{3}$ Pomorski Uniwersytet Medyczny w Szczecinie, Klinika Patologii Noworodka, al. Powstańców Wlkp. 72, 70-111 Szczecin \\ $\triangle$ aciech@pum.edu.pl
}

\begin{abstract}
Introduction: Homo neanderthalensis-derived DNA accounts for an estimated $1-4 \%$ of the genome in contemporary Eurasian populations. The g.50318299 $\mathrm{T}>\mathrm{G}$ (c.1252A $>\mathrm{C}, \mathrm{rs} 35455589)$ transversion of the HYAL2 gene, encoding type 2 hyaluronidase, is in East Asians a highly prevalent marker for the Neanderthal-introgressed haplotype at chromosome 3p21.31. The HYAL2 transversion is in strong linkage disequilibrium with rs11130248 (g.50314769A >G), which predisposes to keloid scarring in the Japanese population. This therefore raises the questions of whether the g.50318299T >G HYAL2 transversion is present in contemporary Poles and whether it predisposes to keloids in our population. Materials and methods: The g.50318299T > G HYAL2 transversion was identified by sequencing genomic DNA samples isolated
\end{abstract}

from the umbilical blood of 200 full-term, healthy newborns and from the peripheral blood of 62 adults with keloids.

Results: There were 2 TG heterozygotes (1\%) and 198 wild-type TT homozygotes (99\%) in the newborn group. Only TT homozygotes were found in the adult group with keloids. The HYAL2 genotype distribution conformed to the expected Hardy-Weinberg equilibrium.

Conclusions: Neanderthal-derived g.50318299T >G HYAL2 transversion rarely presents in the genome of contemporary Poles and is not associated with the predisposition to keloids in this population.

Keywords: Homo neanderthalensis; genetic polymorphism; hyaluronidase; keloid.

\begin{abstract}
ABSTRAKT
Wstęp: Pochodzący od Homo neanderthalensis DNA stanowi ok. 1-4\% genomu w populacjach euroazjatyckich. Markerem rozpowszechnionego u mieszkańców Azji Wschodniej neandertalskiego introgresywnego haplotypu na chromosomie 3p21.31 jest transwersja g.50318299T > G (c.1252A >C, rs35455589) genu HYAL2 kodującego hialuronidazę typu 2. Transwersja HYAL2 jest ściśle sprzężona z polimorfizmem rs11130248 (g.50314769A>G) predysponującym do bliznowca w populacji Japończyków. Stąd też rodzą się pytania, czy transwersja g.50318299T>G HYAL2 występuje również u współczesnych Polaków i czy predysponuje do bliznowca w naszej populacji.

Materiały i metody: Identyfikację transwersji g.50318299T $>\mathrm{G}$ HYAL2 przeprowadzono metodą sekwencjonowania w próbkach
\end{abstract}

genomowego DNA wyizolowanego z krwi pępowinowej 200 zdrowych donoszonych noworodków i z krwi obwodowej 62 dorosłych osób z rozpoznaniem bliznowca.

Wyniki: W grupie noworodków stwierdzono 2 heterozygoty TG (1\%) i 198 homozygot typu dzikiego TT (99\%). W grupie osób dorosłych z keloidem stwierdzono jedynie homozygoty TT. Rozkład genotypów HYAL2 był zgodny z przewidywaną równowagą Hardy'ego-Weinberga.

Wnioski: Pochodząca od człowieka neandertalskiego transwersja g.50318299T >G (rs35455589) genu HYAL2, rzadko obecna w genomie współczesnych Polaków, nie jest związana z predyspozycją do bliznowca w tej populacji.

Słowa kluczowe: Homo neanderthalensis; polimorfizm genetyczny; hialuronidaza; bliznowiec

\section{WSTĘP}

Wyniki badań prowadzonych od opublikowania w $2010 \mathrm{r}$. sekwencji genomu Homo neanderthalensis jednoznacznie wskazują, że między Neandertalczykami a przodkami współczesnego Homo sapiens (już po opuszczeniu przez nich Afryki) doszło do hybrydyzacji (krzyżowania). Szacuje się, że ok. 1-4\% genomu jądrowego współczesnego człowieka w populacjach nieafrykańskich (euroazjatyckich) to DNA pochodzenia neandertalskiego $[1,2,3,4]$. Zwraca uwagę fakt, że DNA Homo neanderthalensis w genomie współczesnego człowieka rozumnego znajduje się głównie w genach związanych z adaptacją do środowiska, m.in. genach kodujących białka warunkujące budowę skóry i włosów oraz biorące udział w reakcjach odpornościowych lub 
w procesach metabolicznych [4, 5, 6, 7]. Wyniki badań asocjacyjnych całego genomu wskazują także na związek niektórych alleli pochodzenia neandertalskiego z predyspozycją do cukrzycy typu 2, choroby Leśniowskiego-Crohna, tocznia rumieniowatego układowego, pierwotnej marskości żółciowej, uzależnienia od papierosów lub nadkrzepliwości [8, 9].

W 2013 r. Ding i wsp. [10] odkryli u mieszkańców Azji Wschodniej wysoką częstość neandertalskiego introgresywnego haplotypu o długości ok. 200 tys. par zasad (pz) na chromosomie 3p21.31. Region ten obejmował loci 18 genów, w tym loci genów: HYAL1, HYAL2 i HYAL3 kodujących odpowiednio: typ 1, typ 2 i typ 3 enzymu hialuronoglukozoaminidaza (hialuronidaza, EC 3.2.1.35), który depolimeryzuje kwas hialuronowy. Według tych autorów bardzo ścisłe sprzężenie swoistej dla neandertalskiego haplotypu w Eurazji transwersji g.50318299T > G (rs35455589) genu HYAL2 (c.1252A >C, p.Ile418Leu) z polimorfizmem rs11130248 (g.50314769A $>$ G) predysponującym do bliznowca u Japończyków [11] sugeruje jej związek z ryzykiem bliznowca również w populacji kontynentalnej Azji Wschodniej [10].

Bliznowiec (bliznowacenie keloidowe, keloid) jest łagodnym, miejscowo agresywnym, fibroproliferacyjnym przerostem blizny przekraczającym jej granicę z zajęciem okolicznej zdrowej skóry [12]. Stąd też pytanie, czy polimorfizm g.50318299T>G (c.1252A>C) genu HYAL2, którego skutkiem jest substytucja izoleucyny przez leucynę w pozycji 418 łańcucha polipeptydowego (p.Ile418Leu) hialuronidazy typu 2, występuje również u Polaków. I jeśli tak, to czy w populacji Polaków polimorfizm ten predysponuje do bliznowca.

\section{MATERIAŁY I METODY}

\section{Grupa noworodków}

Do oceny rozpowszechnienia polimorfizmu rs35455589 (g.50318299T>G) genu HYAL2 w populacji współczesnych Polaków z Banku DNA Zakładu Biochemii Klinicznej i Molekularnej Pomorskiego Uniwersytetu Medycznego w Szczecinie (PUM) losowo wybrano próbki genomowego DNA wyizolowanego z krwi pępowinowej kolejnych 100 zdrowych donoszonych noworodków płci żeńskiej i 100 zdrowych donoszonych noworodków płci męskiej urodzonych w latach 2005-2011 w Klinice Patologii Noworodka PUM. Kryteria wyłączenia obejmowały: poród przed zakończeniem 37. tyg. ciąży, ciąże mnogie, cukrzycę ciężarnych, wewnątrzmaciczne zahamowanie wzrostu płodu (intrauterine growth retardation), aberracje chromosomowe i/lub wady wrodzone. Próbki krwi pępowinowej (ok. $5 \mathrm{~mL}$ krwi pobrane do probówek zawierających 0,1 mL 5\% EDTA) były pobierane za zgodą rodziców dzieci w ramach projektu zaaprobowanego przez Komisję Bioetyczną PUM (BN-001/5/05, KB-0012/31/15).

\section{Grupa dorosłych chorych z bliznowcem}

Polimorfizm rs35455589 (g.50318299T>G) genu HYAL2 identyfikowano w próbkach genomowego DNA wyizolowanego z krwi obwodowej 62 dorosłych chorych (52 kobiet i 10 mężczyzn w wieku 21-70 lat) operowanych z powodu bliznowca w Aesthetic Med w Szczecinie. U 17 chorych bliznowiec był obecny w skórze głowy lub szyi, u 14 chorych na kończynach, a u pozostałych w skórze klatki piersiowej lub brzucha. Bliznowiec pooperacyjny dotyczył 36 chorych, u 9 chorych blizna keloidowa pojawiła się po urazie (przekłucie uszu lub ugryzienie przez owada), a u 6 po oparzeniu. U pozostałych 11 chorych przyczyna bliznowca była nieznana. Liczba zmian skórnych u poszczególnych chorych wynosiła od 1 ( 43 chorych) do 5 ( 1 chory), a pole powierzchni pojedynczych zmian wynosiło $1-40 \mathrm{~cm}^{2}$. U 6 kobiet potwierdzono obecność bliznowca u matki lub u rodzeństwa. Badania przeprowadzono za zgodą Komisji Bioetycznej PUM (KB-0012/135/12).

\section{Metodyka badań molekularnych}

Materiał do badań stanowił genomowy DNA wyizolowany z leukocytów krwi pępowinowej (noworodki) lub obwodowej (osoby dorosłe) zestawem QIAamp® DNA Mini Kit (Qiagen). Polimorfizm rs35455589 (g.50318299T>G) genu HYAL2 identyfikowano metodą sekwencjonowania, jak opisano poprzednio [13]. Primery do PCR i sekwencjonowania (F: 5-GCCCAGCTGTACCCTCCTTCC-3' i R: 5-CACGGCTGCTGGTCCCCTACG-3') zostały zaprojektowane na podstawie sekwencji NC_000003.12 (Homo sapiens chromosome 3, GRCh38.p7 Primary Assembly) pochodzącej z bazy NCBI.

\section{ANALIZA STATYSTYCZNA}

Zgodność rozkładu genotypów HYAL2 z prawem Hardy'egoWeinberga oceniano za pomocą testu $\chi^{2}$, a rozkład tych genotypów w grupie chorych z bliznowcem i w grupie noworodków porównano, stosując dokładny 2-stronny test Fishera. Wartość $\mathrm{p}<0,05$ przyjęto jako próg istotności. Analizę statystyczną wykonywano przy użyciu programu Statistica 7.1.

\section{WYNIKI}

Identyfikację genotypów polimorfizmu rs35455589 (g.50318299T>G) genu HYAL2 kodującego hialuronoglukozoaminidazę typu 2, zarówno w grupie noworodków, jak i u osób dorosłych z keloidem, wykonano metodą sekwencjonowania. Dla każdej analizowanej próbki DNA uzyskano dobrej jakości amplikony, których sekwencje odczytano za pomocą oprogramowania Sequencing Analysis v5.4 (Applied Biosystems) rycina 1.

Rozkład genotypów rs35455589 HYAL2 w grupie noworodków był zgodny z rozkładem teoretycznym wynikającym z równowagi Hardy'ego-Weinberga $(\mathrm{p}=0,920)$. W całej badanej grupie 200 noworodków zidentyfikowano 198 (99,0\%) homozygot TT i 2 heterozygoty (1 noworodek płci żeńskiej i 1 noworodek płci męskiej) TG (1,0\%). Częstość allelu g.50318299G HYAL2 wynosiła w tej grupie 0,5\%. Z kolei w grupie chorych z bliznowcem każda z osób miała homozygotyczny genotyp typu dzikiego TT. 


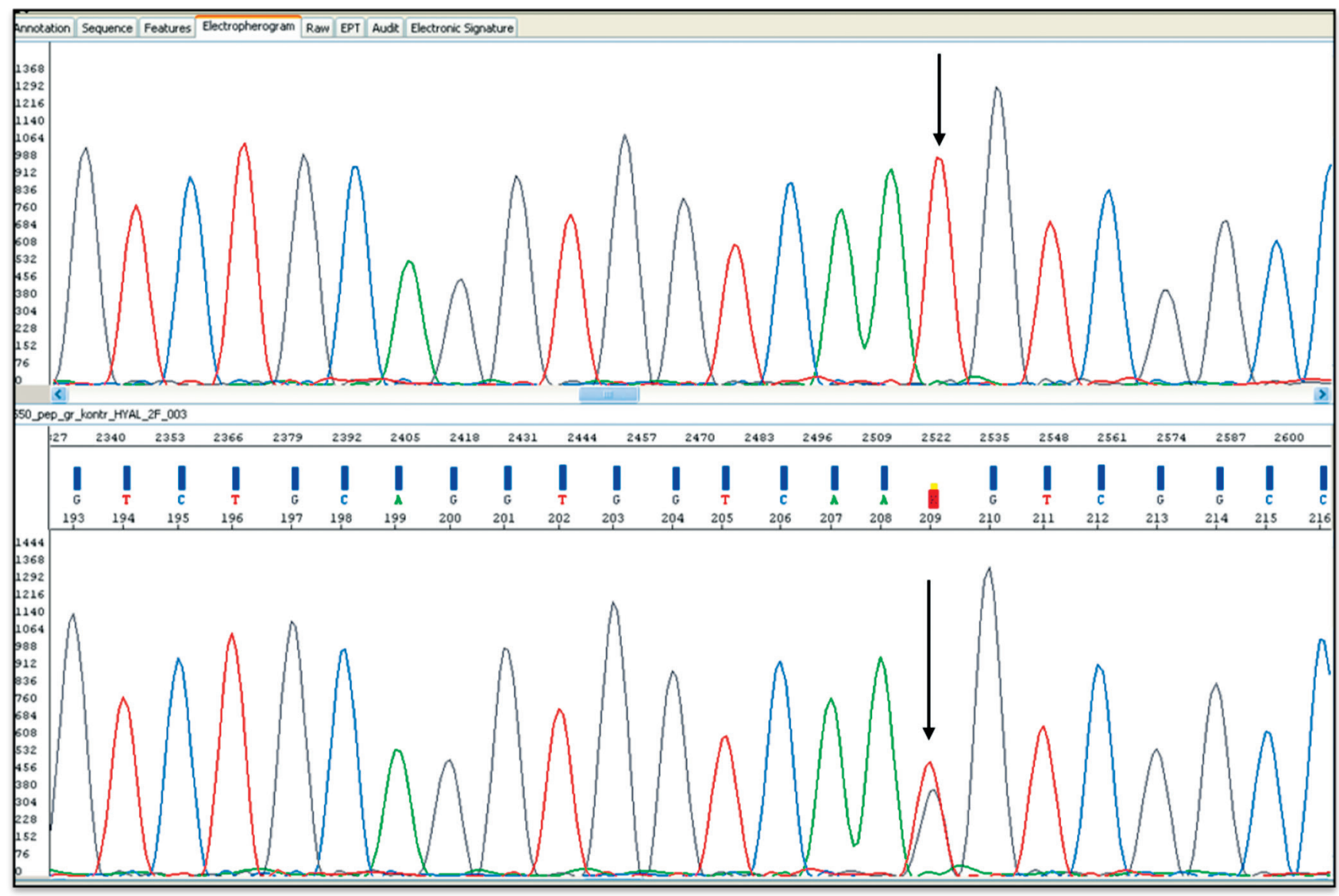

RYCINA 1. Chromatogram sekwencyjny transwersji g.50318299T>G (rs35455589) HYAL2: panel górny - homozygota TT (homozygota typu dzikiego); panel dolny - heterozygota TG

\section{DYSKUSJA}

Odkryta w 2013 r. neandertalska introgresja na chromosomie 3p21.31 występuje z częstością 49,4-66,5\% wśród mieszkańców Azji Wschodniej i jest obecna, ale znacznie rzadziej (<5\%), w niektórych społecznościach europejskich [10]. Ding i wsp. wykryli także sygnał silnej pozytywnej selekcji tego introgresywnego neandertalskiego haplotypu w populacji Azji Wschodniej, wskazując, że prawdopodobnym celem tej selekcji była tranzycja g.50303895C>T (rs12488302) genu HYAL1 i inne allele ściśle sprzężone $\mathrm{z}$ nią $\mathrm{w}$ tym haplotypie, w tym i transwersja g.50318299T >G (rs35455589) genu HYAL2, który koduje hialuronidazę typu 2, enzym związany z odpowiedzią komórki na promieniowanie ultrafioletowe typu B (UV-B) [10]. Wykazanie przez Ding i wsp. w populacjach z Azji Wschodniej ujemnej korelacji $(\mathrm{r}=-0,7508)$ pomiędzy częstością allelu g.50318299G HYAL2 a szerokością geograficzną uważane jest przez tych autorów za ważny argument wspierający ich hipotezę, iż to właśnie zależne od szerokości geograficznej natężenie promieniowania UV-B jest siłą selekcyjną loci genów HYAL [10].

Według danych z projektu 1000 Genomów (www.ncbi.nlm. nih.gov/variation/tools/1000genomes/) częstość uważanego za allel ancestralny wariantu g.50318299G HYAL2 u współczesnych Afrykańczyków wynosi 7,1-23,6\%. Jednak analiza filogenetyczna przeprowadzona przez Ding i wsp. przekonująco wykazała różną historię ewolucji haplotypów regionu chromosomalnego 3p21.31 w populacjach, z których wywodzą się współcześni Afrykanie i w populacjach, z których wywodzą się współcześni mieszkańcy Eurazji. Według tych autorów haplotypy z allelem g.50318299G genu HYAL2 szeroko rozpowszechnione w populacjach, z których wywodzą się współcześni mieszkańcy Eurazji, to raczej skutek krzyżowania z Neandertalczykami niż ich bezpośredniego odziedziczenia od przodków współczesnych mieszkańców Afryki [10].

Według naszej najlepszej wiedzy niniejsza praca jest pierwszym doniesieniem potwierdzającym obecność swoistego dla Homo neanderthalensis allelu g.50318299G (rs35455589) genu HYAL2 w genomie współczesnych Polaków. W badanej przez nas reprezentatywnej dla populacji Polski grupie 200 noworodków częstości: heterozygotycznego genotypu TG i zmutowanego allelu g.50318299G wynosiły odpowiednio 1,0\% i 0,5\%. Wartości te są w pełni zgodne z dostępnymi z projektu 1000 Genomów wynikami identyfikacji genotypów rs35455589 genu HYAL2 w dwóch innych populacjach pochodzenia europejskiego - Brytyjczyków z Anglii i Szkocji oraz mieszkańców stanu Utah (populacja CEPH), których przodkowie pochodzili z Europy Północnej i Zachodniej [10]. Warto też zauważyć, że częstość tranzycji g.50314769A>G (rs11130248) silnie sprzężonej $\left(\mathrm{r}^{2}=1,00\right) \mathrm{z}$ badaną przez nas transwersją g.50318299T > G (rs35455589) genu HYAL2 w małej grupie Rosjan ( $\mathrm{n}=25$ ) wynosiła $2,0 \%$, tj. w grupie tej 
stwierdzono jedną heterozygotę AG [10]. Zwraca uwagę fakt, że transwersja g.50318299T>G HYAL2 nie występuje u Włochów i Hiszpanów, a u Finów częstość występowania zmutowanego allelu G wynosi ponad 4,5\% [10]. I chociaż wyniki te wydają się sugerować, że w populacjach europejskich w przeciwieństwie do populacji wschodnioazjatyckich istnieje dodatnia korelacja ( $\mathrm{r}=0,820 ; \mathrm{p}<0,045)$ pomiędzy częstością allelu g.50318299G HYAL2 a szerokością geograficzną, to należy traktować je bardzo ostrożnie z uwagi na rzadkie występowanie tego allelu w populacji Europy i odrębność genetyczną Finów jako populacji izolowanej [14, 15]. Dodatkowo zarówno w badanej przez nas grupie, jak i u Brytyjczyków oraz w populacji CEPH, a odmiennie niż w populacjach wschodnioazjatyckich, obecne były tylko heterozygoty w zakresie transwersji g.50318299T >G HYAL2 [10].

W badanej przez nas grupie dorosłych chorych z bliznowcem nie stwierdziliśmy nosicieli transwersji g.50318299T $>\mathrm{G}$ genu kodującego hialuronidazę typu 2, co wydaje się sugerować, że polimorfizm ten nie jest czynnikiem predysponującym do rozwoju keloidu u Polaków. Ponadto wyniki naszej analizy przeprowadzonej w oparciu o dane z projektu 1000 Genomów wskazują, że w populacjach europejskich, analogicznie jak ma to miejsce w populacjach azjatyckich, polimorfizm rs35455589 jest równie ściśle (D`: 1,0 i r2: 1,0) sprzężony z będącym czynnikiem ryzyka keloidu u Japończyków polimorfizmem rs11130248 (g.50314769A>G). To z kolei pośrednio sugeruje brak związku polimorfizmu rs11130248 z predyspozycją do bliznowca u Polaków.

Według Ding i wsp. zwiększone ryzyko bliznowca w populacjach azjatyckich i afrykańskich może być związane z rozpowszechnieniem w nich transwersji g.50318299T $>$ G genu HYAL2 [10]. Jednak mimo niskiej częstości nosicielstwa (1,00\%) tej transwersji w naszej populacyjnej grupie kontrolnej i małej liczebności grupy badanej $(n=62)$ nie można ostatecznie wykluczyć jej związku z podatnością do bliznowca u części polskich chorych. W symulacji wykonanej przez nas przy zachowaniu niezmienionych liczebności obu analizowanych grup i częstości allelu g.50318299G HYAL2 w grupie kontrolnej już wykrycie co najmniej 4 nosicieli tej transwersji (częstość nosicielstwa 6,45\%) w grupie badanej okazałoby się czynnikiem ryzyka wystąpienia bliznowca - OR (95\% CI) = 6,83 $(1,22-38,22), p=0,029$.

\section{WNIOSKI}

1. Pochodząca od człowieka neandertalskiego transwersja g.50318299T>G (rs35455589) genu HYAL2 kodującego hialuronidazę typu 2 występuje z niską częstością w genomie współczesnych Polaków.
2. Transwersja g.50318299T >G HYAL2 nie jest czynnikiem predysponującym do bliznowca u Polaków.

\section{PIŚMIENNICTWO}

1. Green RE, Krause J, Briggs AW, Maricic T, Stenzel U, Kircher M, et al. A draft sequence of the Neandertal genome. Science 2010;328(5979):710-22. doi: 10.1126/science.1188021.

2. Yotova V, Lefebvre JF, Moreau C, Gbeha E, Hovhannesyan K, Bourgeois S, et al. An X-linked haplotype of Neandertal origin is present among all Non-African populations. Mol Biol Evol 2011;28(7):1957-62. doi: 10.1093/ molbev/msr024.

3. Vernot B, Akey JM. Resurrecting surviving Neandertal lineages from modern human genomes. Science 2014;343(6174):1017-21. doi: 10.1126/ science.1245938.

4. Sankararaman S, Mallick S, Dannemann M, Prüfer K, Kelso J, Pääbo S, et al. The genomic landscapes of Neanderthal ancestry in present-day humans. Nature 2014;507(7492):354-7. doi: 10.1038/nature12961.

5. Abi-Rached L, Jobin MJ, Kulkarni S, McWhinnie A, Dalva K, Gragert L, et al. The shaping of modern human immune systems by multiregional admixture with archaic humans. Science 2011;334(6052):89-94. doi: 10.1126/science.1209202.

6. Mendez FL, Watkins JC, Hammer MF. A haplotype at STAT2 introgressed from Neanderthals and serves as a candidate of positive selection in Papua New Guinea. Am J Hum Genet 2012;91(2):265-74. doi: 10.1016/j. ajhg.2012.06.015.

7. Mendez FL, Watkins JC, Hammer MF. Neandertal origin of genetic variation at the cluster of OAS immunity genes. Mol Biol Evol 2013;30(4):798801. doi: 10.1093/molbev/mst004.

8. Gittelman RM, Schraiber JG, Vernot B, Mikacenic C, Wurfel MM, Akey JM. Archaic hominin admixture facilitated adaptation to Out-ofAfrica environments. Curr Biol 2016;26(24):3375-82. doi: 10.1016/j. cub.2016.10.041.

9. Simonti CN, Vernot B, Bastarache L, Bottinger E, Carrell DS, Chisholm RL, et al. The phenotypic legacy of admixture between modern humans and Neandertals. Science 2016;351(6274):737-41. doi: 10.1126/science. aad2149.

10. Ding Q, Hu Y, Xu S, Wang J, Jin L. Neanderthal introgression at chromosome 3p21.31 was under positive natural selection in East Asians. Mol Biol Evol 2013;31(3):683-95. doi: 10.1093/molbev/mst260.

11. Nakashima M, Chung S, Takahashi A, Kamatani N, Kawaguchi T, Tsunoda T, et al. A genome-wide association study identifies four susceptibility loci for keloid in the Japanese population. Nat Genet 2010;42(9):786-72. doi: 10.1038/ng.645.

12. Pastuszak-Gabinowska M, Peregud-Pogorzelski J, Łuksza K, Sznelewski P, Brodkiewicz A. Some aspects of molecular bases of keloid formation. Ann Acad Med Stetin 2011;57(2):10-17.

13. Bińczak-Kuleta A, Rubik J, Litwin M, Ryder M, Lewandowska K, Taryma-Leśniak O, et al. Retrospective mutational analysis of NPHS1, NPHS2, WT1 and LAMB2 in children with steroid-resistant focal segmental glomerulosclerosis - a single-centre experience. Bosn J Basic Med Sci 2014;14(2):89-93.

14. Jakkula E, Rehnström K, Varilo T, Pietiläinen OP, Paunio T, Pedersen NL, et al. The genome-wide patterns of variation expose significant substructure in a founder population. Am J Hum Genet 2008;83(6):787-94. doi: 10.1016/j.ajhg.2008.11.005.

15. Lao O, Lu TT, Nothnagel M, Junge O, Freitag-Wolf S, Caliebe A, et al. Correlation between genetic and geographic structure in Europe. Curr Biol 2008;18(16):1241-48. doi: 10.1016/j.cub.2008.07.049. 